\title{
Partial Replacement of Fishmeal by Lyophylized Powder of the Microalgae Spirulina platensis in Pacific White Shrimp Diets
}

\author{
R. Hanel", D. Broekman, S. de Graaf and D. Schnack \\ Leibniz Institute of Marine Sciences, Düsternbrooker Weg 20, D-24105 Kiel, Germany
}

\begin{abstract}
An eleven-week feeding trial was conducted to evaluate the growth effect of partial replacement of fishmeal by the microalga Spirulina platensis in the diet of juvenile Pacific white shrimp Litopenaeus vannamei (Boone). The results clearly indicate that Spirulina platensis constitutes an effective food ingredient for shrimp. Growth rates of a Spirulina-fed group differed highly significantly $(\mathrm{p}<0,001)$ compared to two groups fed to less suitable diets and were slightly, even though not significantly superior to that based on an optimal commercial reference fish diet. As a side effect, Spirulinafed shrimps showed measurable differences in pigmentation.
\end{abstract}

Keywords: Spirulina platensis, feed, protein, growth, shrimp, Litopenaeus vannamei.

\section{INTRODUCTION}

In the last few years, there has been a growing interest in finding and developing alternative protein resources for aquaculture, as fishmeal production has a negative impact on global fishing resources [1]. The assumption that aquaculture decreases the pressure on global fishery resources and provides the world population with protein is only true for herbivorous animals fed with plant derived diets [2]. Existing semi-intensive and intensive farming systems for carnivorous fish and penaeid shrimp are net fish protein reducers rather than net fish protein producers. The total amount of fish and fishery resources used as food exceeds the output of new fish protein by a factor of two to five, depending on the farming system and fishery resources used [3].

Marine shrimp farming operations depend on fishmeal and fish oil as sole or major dietary protein and lipid ingredients in farm-made or commercial aquafeeds [3]. Shrimp are omnivorous organisms, which means that a part of their natural diet is based on plants. Several protein rich vegetable products have already been tested concerning their food quality such as soybeans [4], cottonseeds [5], peanuts [6], rapeseed [7], a mixture of soybean meal and poultry meal [8] and fermented crop, a waste product of the brewing industry [9]. Today, soybean meal is one of the basal ingredients in commercial aquafeed, because of its good quality, low cost and steady availability.

As another possibly valuable feed ingredient we considered the microalga Spirulina platensis, which contains about $60-70 \%$ protein in dry weight [10]. Its amino acid profile is of higher quality than any other plant protein. Further it contains high amounts of vitamins and micronutrients [10]. These facts make this alga interesting in terms of fishmeal replacement. Even though Spirulina has been used extensively as human food supplement [11], its use as an animal food supplement is rather recent. Spirulina species have already been tested as a substitute protein source for Cyprinus

\footnotetext{
*Address correspondence to this author at the Department of Fisheries Biology, Leibniz Institute of Marine Sciences, Düsternbrooker Weg 20, D24105 Kiel, Germany; E-mail: rhanel@ifm-geomar.de
}

carpio, where equal or even higher growth rates were obtained by diets containing $25 \%$ algae meal, replacing $80 \%$ of the dietary fishmeal [12]. The effect of supplementation of Spirulina in the diet was also studied in the giant freshwater shrimp (Macrobrachium rosenbergii) [13], where Spirulina meal significantly improved growth, survival and feed utilization irrespective of the supplementation level in the range of $5-20 \%$ in the feed. The authors suggested that the improved growth and feed utilization was probably due to enhancement of protein assimilation (see also [14]). Further, Spirulina algae have high contents of pigments such as BetaCarotin, which has an influence on the pigmentation of the integument of the culture animals [15].

In the present study, we aim to determine the effect of partial replacement of fishmeal with Spirulina for juvenile Pacific white shrimp Litopenaeus vannamei [16] under commercial conditions in a re-circulation system in comparison to a commercial reference aquafeed and another plant rich diet. We further tested the food quality of bacterial mud, a waste product of the biofilter of the re-circulation system, as preliminary trials proved the high feed acceptance of dried mud by the shrimp.

\section{MATERIALS AND METHODS}

\section{Recirculation System and Tank Culture}

Pacific white shrimp (Litopenaeus vannamei) postlarvae were obtained from a commercial hatchery in Florida, USA and reared to initial trial size at Ecomares-Marifarm facilities in Strande, Germany. They were cultured in tanks connected to a recirculation system with steady reprocessing of polluted waters. A total water volume of approximately $30 \mathrm{~m}^{3}$ with a salinity of $21 \mathrm{gL}^{-1}$ and a temperature between $26^{\circ} \mathrm{C}$ and $28^{\circ} \mathrm{C}$ underwent several clearing stages. These stages, consisting of two settling tanks, a lamella separator and a station for biological treatment with denitrificant bacteria, were passed with the use of an electrical pump. A protein skimmer and a UV-lamp were also installed. Oxygen was provided through additional aeration. In this system a continuous influx of 5$10 \%$ of the total water volume per day from the Kiel bight was maintained to compensate the loss through evaporation. $100 \mathrm{~L}$ culture tanks were used with a flow-through-rate of 13,5 L per hour. For each experimental diet two replicate 
tanks were applied, each subdivided into 4 compartments so that a total of eight replicates were obtained per diet. Airstones kept dissolved oxygen levels at $7 \mathrm{mgL}^{-1}$. The stocking density was 80 shrimp per square meter (i.e. 20 animals per compartment) showing an average initial wet weight of $8.41 \pm 1.58 \mathrm{~g}(\mathrm{n}=480)$ each. For the bacteria trial two $64 \mathrm{~L}$ aquariums were connected to the recirculation system with a through flow rate of $48 \mathrm{~L}$ per hour. 10 shrimps were kept in each aquarium ( 25 shrimps per square meter) with an initial weight of $8.90 \pm 1.84 \mathrm{~g}(\mathrm{n}=20)$. During the experiment no critical values for ammonia or nitrite were detected. An artificial lighting system was set to a daily cycle of 14-h light/10-h dark.

\section{Experimental Diets}

Three experimental diets and a reference diet were used. The first experimental diet contained the microalga Spirulina platensis and was formulated by adding a pure lyophylized powder of the algae (BlueBioTech, Buesum, Germany) to a commercial carp feed (Art-No: 10936 000, "Alleinfutter für Karpfen”, Koelln, Elmshorn, Germany) containing 5\% fishmeal according to manufacturer's specifications, which was ground prior to mixing, in a ratio of 1:1. Pellets of $2.5 \mathrm{~mm}$ diameter were produced. The second experimental diet, commercial carp feed, was equally ground due to the initially too large pellet size and passed through the same $2.5 \mathrm{~mm}$ die. Manufacturer information on the used commercial diets is given in Table 1. The third experimental diet, bacterial mud, was collected from either the sediment tank or from the lamella separator. The mud was assembled and dried on a finely woven net (mesh size $0.5 \mathrm{~mm}$ ) one day before serving as food. The reference diet was a commercial fish feed (DAN-EX 1344, Dana-Feeds A/S, Horsens, Denmark) used successfully for shrimp culture at Ecomares-Marifarm and therefore regarded as an optimal diet, having a pellet size of $2 \mathrm{~mm}$ diameter. The experimental diets were analyzed for protein [17], lipid [18] and moisture content by subtracting the mass of 12 hour oven-dried pellets from the mass prior to drying (Table 2).

Table 1. Manufacturer Information on the Two Commercial Diets Used

\begin{tabular}{|l|l|}
\hline \multicolumn{1}{|c|}{ Dana-Feed } & \multicolumn{1}{c|}{ Carp-Feed } \\
\hline \hline $43.20 \%$ Fishmeal & Wheat \\
\hline $19.00 \%$ Wheat & Soybean \\
\hline $18.03 \%$ toasted Soybean & $5 \%$ Fishmeal \\
\hline $10.00 \%$ Soybean & Toasted Soybean \\
\hline $5.00 \%$ Sunflower seeds & Fish oil \\
\hline $4,07 \%$ Fish oil & Minerals \\
\hline $0,70 \%$ Vitamin premix & Vitamin- and trace element premix \\
\hline
\end{tabular}

\section{Experimental Procedure}

The experiment was run over a period of 11 weeks (76 days). The shrimp in each of the four feeding groups were fed twice a day at a ratio of $4 \%$ of biomass with the rations being adjusted in a four-week interval according to the achieved weight. After a few preliminary tests, the amount of bacterial mud for feeding was established at $40 \%$ of initial mean body weight. This amount was necessary to constantly keep the intestines of the shrimp filled and therefore prevent them from starving. At the start and at the end of the experiments, the shrimp were weighed individually to the nearest $0.01 \mathrm{~g}$, using a digital balance (Sartorius, Goettingen, Germany). After four and eight weeks, intermediate measurements were made for groups of shrimps to identify the average weight of shrimps in each container. The body mass of the mud fed shrimp was determined in an interval of two weeks. Dead animals and exuviae were removed from the tanks daily. The difference between initial and final weight of the groups of shrimp per container were used to measure the average growth rate per day.

Table 2. Contents of Macronutrients in the Four Experimental Diets

\begin{tabular}{|l|c|c|c|c|}
\hline Content in \% & Spirulina + Carp & Dana & Carp & Bacteria \\
\hline \hline Proteins & 44.7 & 45.7 & 27.2 & 4.0 \\
\hline Lipids & 7.5 & 12.9 & 5.1 & 0.5 \\
\hline Moisture & 10.2 & 5.8 & 11.8 & 89.5 \\
\hline
\end{tabular}

Further, at the end of the experiment five specimens of each feeding group were put into boiling water for approximately ten minutes for the orange coloration to appear and then were compared using a Roche-Scale (Roche Pharmaceuticals, Basel, Switzerland) to determine the intensity of pigmentation.

To test whether the animals can influence their own pigmentation, ten individuals were put either in a white or a black tank for the course of the experiment. In the end they were put into boiling water to compare pigmentational appearance.

\section{Statistical Analysis}

The differences in average growth rates among treatments were tested for statistical significance by analysis of variance (ANOVA) and Tukey's HSD Test on. The ANOVA did not include the data of the bacteria trial, since the bacteria fed shrimp exhibited almost zero growth over the experimental period.

Statistical analyses were done with STATISTICA 6.0 (StatSoft, Tulsa, OK, USA). Statistical significance was set at $\mathrm{p} \leq 0.05$ for all factors.

\section{RESULTS}

The effects of different diets on growth rate are summarized in Fig. (1). Starting from similar sizes, the absolute highest final weight was observed for the Spirulina-fed shrimp (14.81 g $\pm 0.27 \mathrm{SE}, \mathrm{n}=96$ ). The shrimp fed on commercial fish feed (Dana) showed a final weight of $14.48 \mathrm{~g} \pm$ $0.29 \mathrm{SE}, \mathrm{n}=97$, those fed with carp feed were at $13.13 \mathrm{~g} \pm$ $0.23 \mathrm{SE}, \mathrm{n}=103$ and the bacteria fed shrimp had a mean weight of $9.31 \mathrm{~g} \pm 0.42, \mathrm{n}=17$.

Average growth rate of the Spirulina-fed shrimp was 86 $\mathrm{mg}$ /day over the experimental period (Table 3). This growth rate was slightly superior to that based on the optimal commercial fish diet (Dana), which amounted to $78 \mathrm{mg}$ /day, but 
the observed difference was not statistically significant. The animals fed on carp feed, however, showed a significantly lower growth of $61 \mathrm{mg} /$ day $(\mathrm{p} \leq 0.001)$. The bacteria fed shrimp hardly gained any weight (Fig. 1).

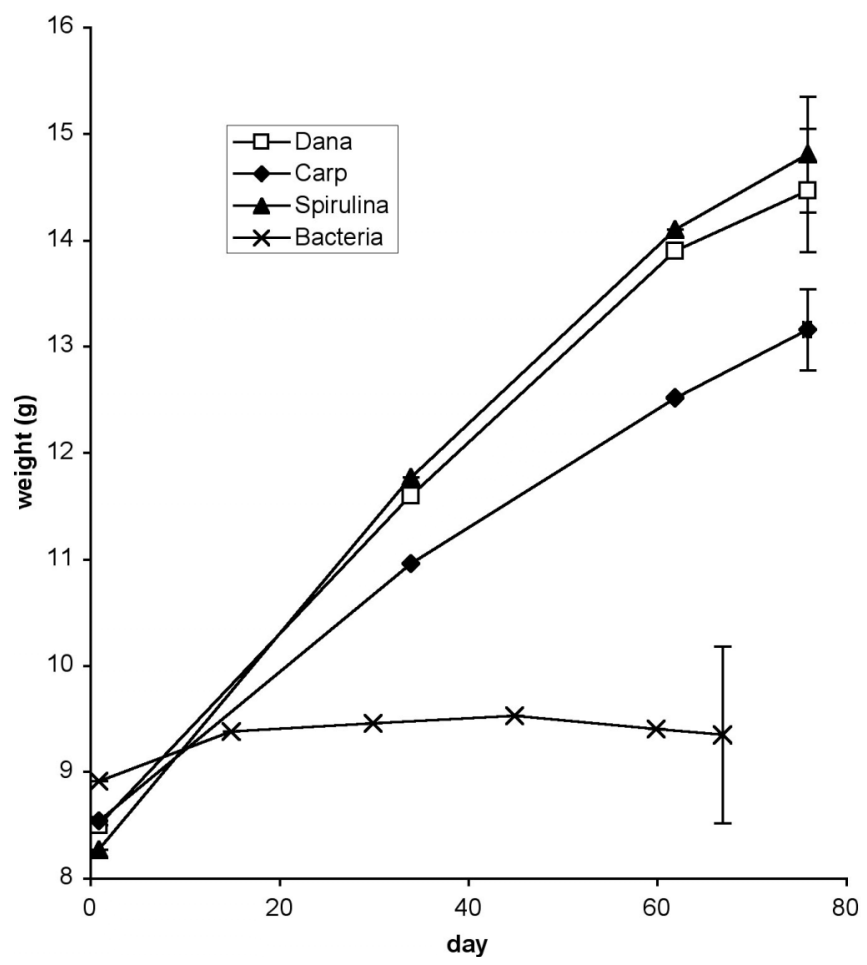

Fig. (1). Weight gain in Litopenaeus vannamei fed commercial carp feed (Carp), Spirulina enriched carp feed (Spirulina), bacterial mud (Bacteria) and a commercial reference feed (Dana) for a total of 76 days. Mean weights and corresponding 95\% confidence intervals from all individuals measured per diet group.

A distinct difference in growth rate was observed among the successive observation periods (Fig. 1). During the first month the shrimp of the Spirulina-fed group showed an average growth of $103 \mathrm{mg} /$ day and the carp feed group a significantly lower rate of $71 \mathrm{mg} / \mathrm{day}$. In the second month growth rates were slightly reduced but still high, with 83 $\mathrm{mg}$ /day in the Spirulina-fed group and again a significantly lower value of $56 \mathrm{mg} / \mathrm{day}$ in the carp feed group. A more pronounced reduction in growth was observed in the last period, with values between 50 and $40 \mathrm{mg}$ /day (except bacteria fed group) and no statistical difference among the three positive treatments.
Further, we observed a distinct pigmentation, as measured with a Roche-Scale [19] of the integument of the shrimp fed on Spirulina (31 Rsc) which was 11 numbers higher than of those fed on the commercial diet (20 Rsc) and 7 numbers higher than those fed on the carp diet (24 Rsc) (Fig. 2). No differences of pigmentation could be observed within feeding groups. Pigmentation of the shrimp held in white or black tanks differed, as those from white tanks showed 19 Rsc and those from black tanks 22 Rsc (Fig. 3).

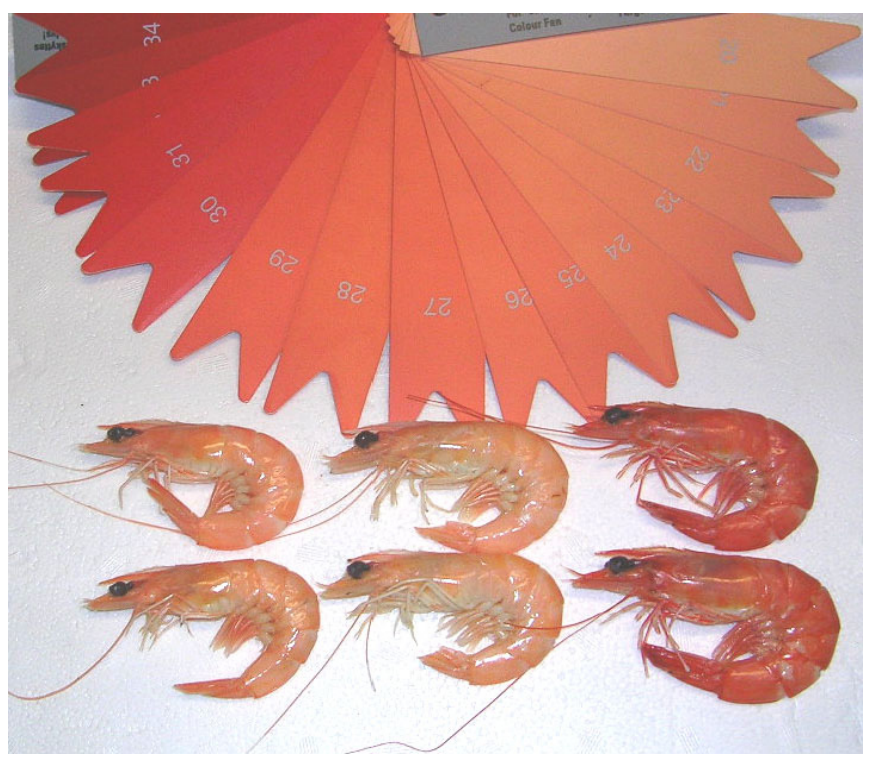

Fig. (2). Pigmentation of Litopenaeus vannamei fed commercial carp feed (left), a commercial DANA reference feed (center) and Spirulina enriched carp feed (right) after boiling in water for 10 minutes under a Roche SalmoFan ${ }^{\mathrm{TM}}$ (Roche Pharmaceuticals, Basel, Switzerland).

\section{DISCUSSION}

Growth rates of the experimental shrimp observed during the present trials ranging from 0.04 to $0.10 \mathrm{~g}$ /day were rather low compared to previously published data, which ranged from 0.11 to $0.19 \mathrm{~g} / \mathrm{day}$ [20] to $0.26 \mathrm{~g} / \mathrm{day}$ [21]. This indicates that the daily feed ratio of $4 \%$ of biomass may not have been enough to allow optimal growth. The decreasing growth rates over the trial period may be attributed to approaching adulthood and partly to a slight reduction of daily food administration over the last two weeks of the growth trial.

The similarly high growth rates obtained with Spirulina feed and commercial shrimp diet, and the lower growth rates

Table 3. Initial and Final Mean Weights and Corresponding Standard Deviations from all Individuals Measured Per Diet Group; Average Growth Rates and Standard Deviations are Derived from Eight Replicate Groups for Diets 1-3, and from Total Mean and Variance of Initial and Final Weights for Bacterial Food

\begin{tabular}{|l|c|c|c|c|c|c|}
\hline \multirow{2}{*}{ Diet } & \multicolumn{2}{|c|}{ Initial Mean Weight (g) } & \multicolumn{2}{c|}{ Final Mean Weight (g) } & \multicolumn{2}{c|}{ Growth Rate (mg/day) } \\
\cline { 2 - 7 } & $\mathbf{x} \pm \mathbf{s d}$ & $\mathbf{n}$ & $\mathbf{x} \pm \mathbf{s d}$ & $\mathbf{n}$ & $\mathbf{x} \pm \mathbf{s d}$ & $78 \pm 7$ \\
\hline \hline 1 Dana & $8.49 \pm 1.68$ & 160 & $14.48 \pm 2.87$ & 97 & $61 \pm 13$ & 8 \\
\hline 2 Carp & $8.50 \pm 1.57$ & 160 & $13.13 \pm 2.33$ & 103 & $86 \pm 11$ & 8 \\
\hline 3 Spirulina & $8.26 \pm 1.59$ & 160 & $14.67 \pm 2.69$ & 96 & $6.2 \pm 38$ & 37 \\
\hline 4 Bacteria & $8.90 \pm 1.89$ & 20 & $9.31 \pm 1.72$ & 17 & 8 \\
\hline
\end{tabular}






Fig. (3). Difference in pigmentation of Litopenaeus vannamei held in black (1) and white (2) tanks, shown for living (left picture) and boiled (right picture) specimens.

obtained with carp diet shows that a replacement of a large amount of fishmeal can in fact be achieved in an aquatic animal diet. The Spirulina-diet contained approximately $10 \%$ fishmeal but resulted in very good growth and survival compared to the other feeding groups. Wilson and Poe [22] state that the dietary protein with the maximum physiological advantage is when the amino acid profile resembles as much as possible to that of the consumer, which is the reason for the fact that cultured aquatic organisms are preferably fed with animal protein. However, this study clearly points to the suitability of the microalga Spirulina platensis to meet the nutritional needs of the shrimp Litopenaeus vannamei at least in terms of protein composition. It can be assumed that some kind of other nutritional factors like minerals and vitamins further add up to the good nutritional quality and applicability of the algae.

Regarding the weak growth of the carp diet-fed shrimp, it can be stated that not only the amount but also the quality of the protein offered here, was obviously not adequate. Previous studies [23] determined an optimum dietary protein content of $28 \%$ to $32 \%$ for juvenile Litopenaeus setiferus. This indicates that the protein content of the carp feed of about $27 \%$ was not much too low for growth but that the quality of the protein was too low for optimum growth. Comparing the two plant protein sources utilized here, the Spirulina-protein is obviously more adequate in its nutritional value for shrimp.

In general, microorganisms like e.g. in yeasts contain large amounts of good quality protein and nutrients. The amino acid profile of the algae Spirulina platensis is comparable to that of other microorganisms [24]. However, the feeding of shrimp with bacterial biomass in this trial did not show any growth success, indicating a low nutritional value.

Nutritional carotenoids are deposited in the integument of crustacea. They appear dark blue or grey in vivo. When boiled, the carrier proteins holding the pigments denature and thereby release them, which can be observed as the appearance of an orange coloration. This effect of a stronger pigmentation in the Spirulina-fed shrimp is important for the shrimp farmer because consumers prefer intensively pigmented cultured shrimp over paler ones and thereby may enhance their commercial value by a factor of ten [25]. Therefore, shrimp fed Spirulina platensis do not require any additional synthetic pigments. Further, it is also recommendable to apply black/dark culture tanks to intensify coloration.

\section{ACKNOWLEDGEMENTS}

We wish to thank Dr. Sebastian Lippemeier and BlueBioTech GmbH for the kind supply of the Spirulina-powder as well as Dr. Gerrit Quantz and Marcus Thon from ECOMARES MariFarm GmbH for their kind support and cooperation. Dr. Harmut Rehbein and his group essentially supported us doing the chemical analyses of the diets in their lab in the German Federal Research Centre for Nutrition and Food in Hamburg. Further we like to thank Mr. Bentien for grounding and pelleting our feeds. Helgi Mempel and Dr. Catriona Clemmesen kindly provided helpful advice.

\section{REFERENCES}

[1] Naylor RL, Goldburg RJ, Primavera JH, et al. Effect of aquaculture on world fish supplies. Nature 2000; 405: 1017-24.

[2] Williams MJ. Murky Waters: Environmental Effects of Aquaculture in the United States (Environmental Defense Fund, New York, 1997). In: Bardach JE, Ed. Sustainable Aquaculture; 1997: Wiley, New York; pp. 15-51.

[3] Tacon AGJ. International Aquafeed Directory and Buyers' Guide 1997/98. Middlesex, UK: Turret RAI; 1996.

[4] Akiyama DM. Soybean meal utilization by marine shrimp. In: Akiyama DM and Tan RKH, Eds. Proceedings of the aquaculture feed processing and nutrition workshop; 1991: American Soybean Association, Singapore; pp. 207-225.

[5] Lim C. Substitution of cottonseed meal for marine animal protein in diets for Penaeus vannamei. J World Aquac Soc 1996; 27: $402-$ 9.

[6] Lim C. Replacement of marine animal protein with peanut meal in diets for juvenile white shrimp Penaeus vannamei. J Appl Aquac 1997; 7: 67-78.

[7] Cruz-Suarez LE, Ricque-Marie D, Tapia-Salzar M, McCallum IM, Hickling D. Assessment of differently processed feed pea (Pisum sativum) meals and canola meal (Brassica $s p$ ) in diets for blue shrimp (Litopenaeus stylirostris). Aquac 2001; 196: 87-104.

[8] Davis DA, Arnold CR. Replacement of fishmeal in practical diets for the Pacific white shrimp, Litopenaeus vananmei. Aquac 2000; 185: 291-8.

[9] Molina-Poveda C, Morales ME. Use of a mixture of barley-based fermented grains and wheat gluten as an alternative protein source in practical diets for Litopenaeus vannamei (Boone). Aquac Res 2004; 35: 1158-65.

[10] Paoletti C, Vincenzini M, Bocci F, Materassi R. Composizione biochimica generale delle biomasse di Spirulina platensis e $S$ maxima. In: Materassi R Ed. Prospettive della coltura di Spirulina in Italia, 1980: Consiglio Nazionale delle Ricerche Rome; pp. 111-25. 
[11] Ciferri O, Tiboni O. The biochemistry and industrial potential of Spirulina. Ann Rev Microbiol 1985; 39: 503-26.

[12] Sandbank, E, Hepher, B. The utilization of microalgae as a feed for fish. Arch Hydrobiol Suppl Ergeb Limnol 1978; 11: 108-20.

[13] Nakagawa H, Gomez-Diaz G. Usefulness of Spirulina sp. meal as feed additive for giant freshwater prawn, Macrobrachium rosenbergii. Suisanzoshoku 1995; 43: 521-6.

[14] Belay A, Kato T, Ota Y. Spirulina (Arthrospira): potential application as an animal feed supplement. J Appl Phycol 1996; 8: 303-11.

[15] Becker EW. The legislative background for utilization of microalgae and other types of single cell protein. Arch Hydrobiol 1978; 11: 56-64.

[16] Boone L. Anomuran, Macruran Crustacea from Panama and Canal Zone. Bull Amer Mus Nat Hist 1931; 63: 1-180.

[17] Kjeldahl J. Eine neue Methode zur Bestimmung des Stickstoffes in organischen Körpern. Fresenius Z Anal Chem 1883; 22: 366.

[18] Smedes F. Determination of total lipid using non-chlorinated solvents. Analyst 1999; 124 (11): 1711-18
[19] Robert N, Coulmier D, Divanach P, Cuzon G. PX Aqua, an alfalfa protein and pigment concentrate for fish and shrimp feeds. World Aquac 2003; 34 (3): 12-16.

[20] Smith LL, Lee PG, Lawrence AL, Strawn K. Growth and digestibility by three size of Penaeus vannamei (Boone): Effects of dietary protein level and protein source. Aquac 1985; 46: 85-96.

[21] Menz A, Blake BF. Experiments on the growth of Penaeus vannamei (Boone). J Exp Mar Biol Ecol 1980; 48: 99-111.

[22] Wilson RP, WE Poe. Effects of feeding soybean meal with varying trypsin inhibitor activities on growth of fingerling channel catfish. Aquac 1985; 46 (1): 19-25.

[23] Andrews JW, Lowell VS, Garry JB. The influence of dietary protein and energy levels on growth and survival of penaeid shrimp. Aquac 1972; 1: 341-7.

[24] Jones A. World protein resources. Lancaster, UK: MTP Publishers; 1974.

[25] Lorenz RT. A review of the carotenoid, Astaxanthin, as a pigment and vitamin source for cultured Penaeus prawn. PhD thesis (www.cyanotech.com); 1998. 